\title{
THE ANALYSIS OF THE CREATIVE INDUSTRY LINKED IN CONNECTION WITH THE ECONOMIC DEVELOPMENT
}

\author{
Jitka Kloudová, Ondřej Chwaszcz
}

\section{Introduction}

We consider the ability of creative thinking to be the basic element of the social development. This unique ability influences not just the quantity and quality of goods produced [15]. It also shapes the socio-cultural development of a society. The influence of the creativity on the progress of the society is becoming more and more intensive. The fact is properly analysed among scientific theories by the creative economy [12], [13]. This theory is based on the growth theories and supplements them with a socio-cultural and urban aspect. Among main authors dealing with creativity, we count Jane Jacobs [8], [9], Charles Landry [16], John Howkins [7], Richard Florida [4] etc.

This development has significantly influenced the structure of economy itself [10] and enabled the creation of a new concept of "creative industries" [3]. The formal roots of this concept originated in Great Britain (1997) where the labor government of Tony Blair established the Department of Culture, Media and Sport (DCMS). This was founded to monitor the creative industries in other countries. However, it is necessary to add that there is no unitary definition of creative industries. One reason is the ambiguous definition which tries to capture inputs, products and services [2]. The other is the divergent cultural background of every country.

Despite the presence of these inconsistencies, we can note that creative industries play a significant role in economy of every European country and their importance will be increasing. This is confirmed by the fact that in the years 2000-2005 the average rise in the international trade with creative products was $8.7 \%$. The value of export of the creative goods and services reached almost 425 billion dollars in 2005. This represents the $3.4 \%$ of the total number of world trade (UNCTAD). The sales within creative industries were calculated at 654 billion dollars in 2003, it grows twelve times faster than total economy of European Union. In addition the creative industries create 5.6 million of job vacancies in Europe [18].

Many significant scientists have been dealing with the creative industries. Among these we refer to not mentioned authors such John Harley [5] and David Hesmondhalgh [6]. Concerning the analysis of creative industries in the Czech Republic these regional attempts should be mentioned: Rumpel, Slach \& Koutsky [17] or Bednar \& Grebenicek [1]. There were also attempts to analyze creative industries on the national level Kloudová [12], Jircikova [11]. The goal of this work is to carry out the analysis of creative industries within the individual regions of the Czech Republic. The structure of the analysis is based on the relation between creative industry and the total performance of the economy. This relation is analyzed not just from the static point of view, the included long-term trend secures dynamic perspective on the area researched.

\section{The Creation of Hypothesis and Methodological Procedures}

The basic presumptions of this study are based on the fact that creative industries are booming rapidly in the developed countries. They are becoming the significant element of regional development and competitiveness. The Czech Republic belongs to the countries of Central 
Europe. These countries started the process of political and economic transformation at the turn of 80's and 90's. The previous comparative advantage of cheap labor has been disappearing and there is a need for seeking of new possible ways of development.

Based on this fact the first hypothesis was determined. This assumes more significant development of the creative industry than of total economy. The study expects that this trend is to be caused by closing the gap between Central and Western Europe together with the effort for maintaining of competitiveness. The level of the creative industry boom should correspond to the level in Western countries in last few years.

The other hypothesis is dealing with the relation between the presence of the creative industry and some basic macroeconomic indicators; at this point, the existence of positive correlation linkage is presumed. This fact would confirm the significant function of creative industries within the economies of the developed countries. The nature of the creative industries should be likely to show higher level of creative industries in the regions tied to a huge urban agglomeration.

On the basis of determined hypotheses the methodology was selected. This methodology proceeds from the DCMS structure. On the other hand it is simplified and corresponds to basic classification of economic activities (NACE). The structure is nowadays used by both Czech and European statistic offices. It is documented by this study that this method is applicable within international comparison, too. The areas included in the creative industry are related to both Information and Communication (laC) as same as Professional, Scientific and Technical activities (PSTa). From the range of NACE these items belong to the group $\mathrm{J}$ and $\mathrm{M}$ (Tab. 1).

\section{Tab. 1: The selected structure of industry (NACE) classified in the creative industry}

\begin{tabular}{l|l|l|l} 
J & Information and communication & M & $\begin{array}{l}\text { Professional, scientific and technical } \\
\text { activities }\end{array}$ \\
\hline J58 & Publishing activities & M70 & $\begin{array}{l}\text { Activities of head offices; management } \\
\text { consultancy activities }\end{array}$ \\
\hline J59 & $\begin{array}{l}\text { Motion picture, video and television } \\
\text { programme production, sound recording } \\
\text { and music publishing activities }\end{array}$ & M71 & $\begin{array}{l}\text { Architectural and engineering activities; } \\
\text { technical testing and analysis }\end{array}$ \\
\hline J60 & Programming and broadcasting activities & M72 & Scientific research and development \\
\hline J61 & Telecommunications & M73 & Advertising and market research \\
\hline J62 & $\begin{array}{l}\text { Computer programming, consultancy } \\
\text { and related activities }\end{array}$ & M74 & $\begin{array}{l}\text { Other professional, scientific and technical } \\
\text { activities }\end{array}$ \\
\hline J63 & Information service activities & M75 & Veterinary activities \\
\hline
\end{tabular}

For a verification of the relation between the creative industry and macroeconomic indicators the work creates new Index of Creative Industry (CII) for each region. The structure of this index is based on the relation between the presence of a creative industry in the region and its average value in all regions. The resulting index is analyzed by the application of the correlation analysis together with some macroeconomic indicators. This provides the answer to the other hypothesis of this study.

\section{The Development of Creative Industry in the Czech Republic}

The basic indicator, which captures the development creative industry production in common prices within the years 1990-2010, confirms the increasing trend of a production. The worldwide financial crisis caused slight decrease in PSTa and at the same time cut the booming trend of laC in 2009 and 2010. Yearon-year the PSTa decreased by $-6.6 \%$ in 2008-2009. However, in comparison to total economy performance which decreases by 


\section{Ekonomie}

$9.0 \%$ the creative industries detected lower downswing. The laC even raised by $1.6 \%$ in the same period. The whole period is captured in the following figure.

\section{Fig. 1: The production by the area (CZ-NACE) - in mil. CZK, common prices}

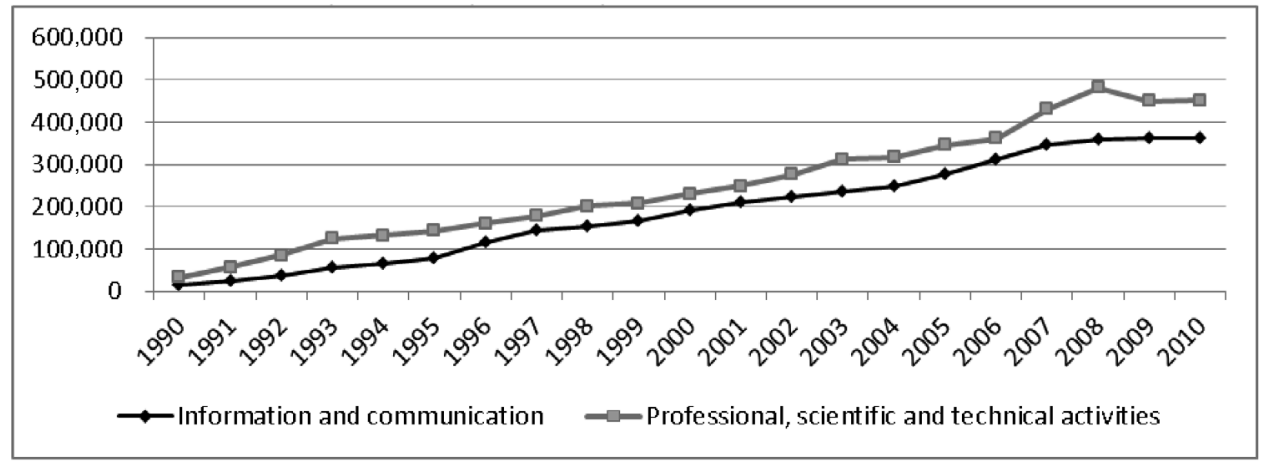

Source: Czech Statistical Office; own calculations

The next figure is dealing with similar statistic as a previous one. This figure links the production in the observed period to year of 1990 , which has the value set at the level of 100. We can notice that the production of laC area grown more rapidly. The production was eight times higher in 2010 than in 1990. In comparison to the overall economy it is extreme increase. Identically, the PSTa have reached almost double growth than the overall economy growth in the same period. This fact confirms the constantly increasing importance of the creative industries in this period of time. At the same time we need to add that the creative industry was at almost zero level before 1990. The door to the development of the creative industries was open widely with the transformation to the market economy.

\section{Fig. 2: The production - volume indexes (year $1990=100)$ - by the area (CZ-NACE), $\%, 1990=100$}

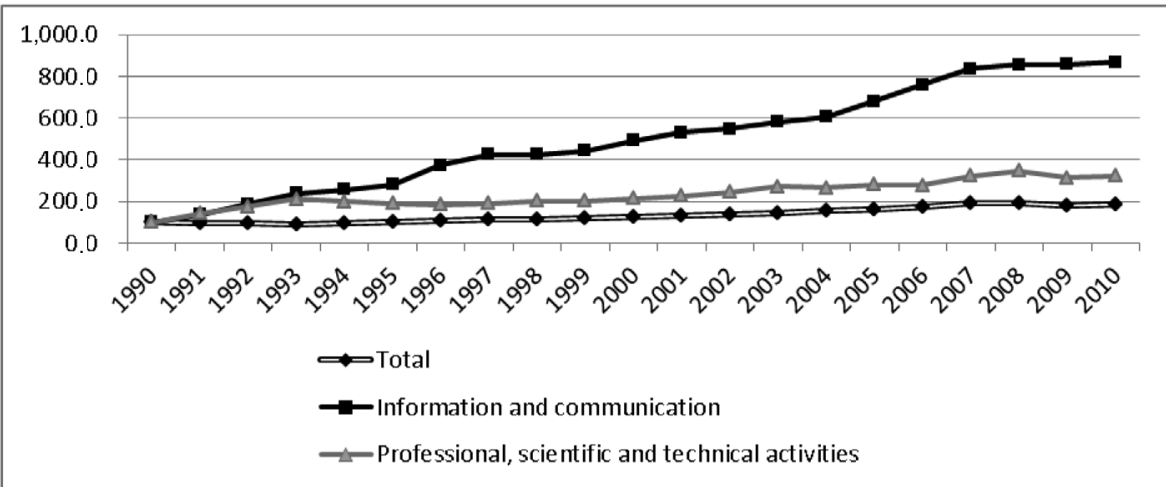


Besides the volume of the production, it is necessary to observe the development of international trade of the creative industries. It was already mentioned that the international trade with the outputs of creative industries reaches higher increase than average indicators of the international trade. The outputs of the creative industries are usually easily tradable so they can support the export of the given area or its economic development. Therefore individual regions should seek an expansion of the creative industries.

The export of goods and service from creative industries keeps an increasing trend in the Czech Republic (Figure 3). However, there was a decreasing trend detected in some years. The more important information at the figure is a fact that the increasing trend was slow in the observed period (1990-2003). The growth in the following years was even more significant. We can assume that the Czech Republic could not compete with its creative industries products and services of the Western countries at beginning of economy transformation. Therefore the export was focused on export of products from other economic areas. Recently, the trend of exporting the products from creative industries has reached high level. This indicates that the Czech Republic has transformed successfully into developed economy.

The export of goods and services (FOB) - by commodities (CZ-CPA) - mil/CZK, common prices

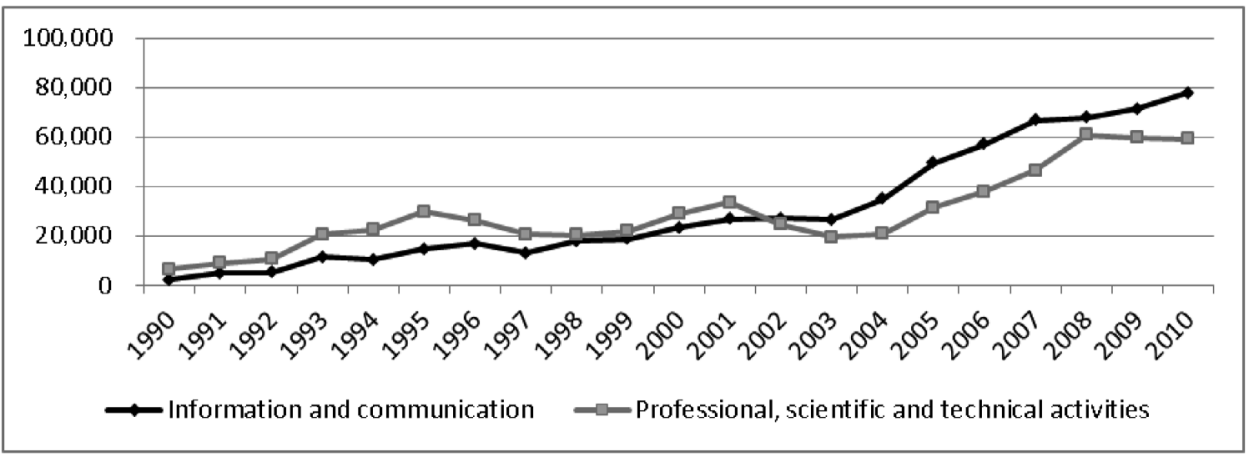

Source: Czech Statistical Office; own calculations

Another significant contribution of the creative industries is the creation of new job vacancies. These demand the higher education and therefore the better remuneration and higher taxation. In comparison to the increase of the level of production there is not such a significant change in the amount of people employed. However, even here the increase occurred. In the observed period the ratio of the people employed within the creative industries was raised by $2.78 \%$. The Figure 4 shows the development of individual sections of creative industry in the Czech Republic. The higher employment rate is detected at PSTa (2010 - 5.63\%).

The new job vacancies within the creative industry create the higher salaries stratum which spends its money within the region and supports the economy of the region. The Figure
5 documents this by the average salary of the creative industry, which is compared with the total average salary. The average salary in both sections of the creative industries has been growing faster than the average salary in the whole economy. The salaries did almost not differ before 1990. With the outset of the market economy the labor market was released and the salary derived from the kind of the work.

The areas of laC were exceeding the average salaries in economy by $46 \%$. It became even $86 \%$ in 2003 . It was less striking in the area of PSTa. Nevertheless, the salaries in this area were higher by $10 \%$ in 1990 and by $23 \%$ than the total average salary of the economy. The percentage difference between the salaries in 2003 corresponds to the difference in the following years. 


\section{Ekonomie}

\section{Employees in the national economy - according to economic area (CZ-NACE) - the figure represent the development of the creative industry employment ratio to all employees in the industry}

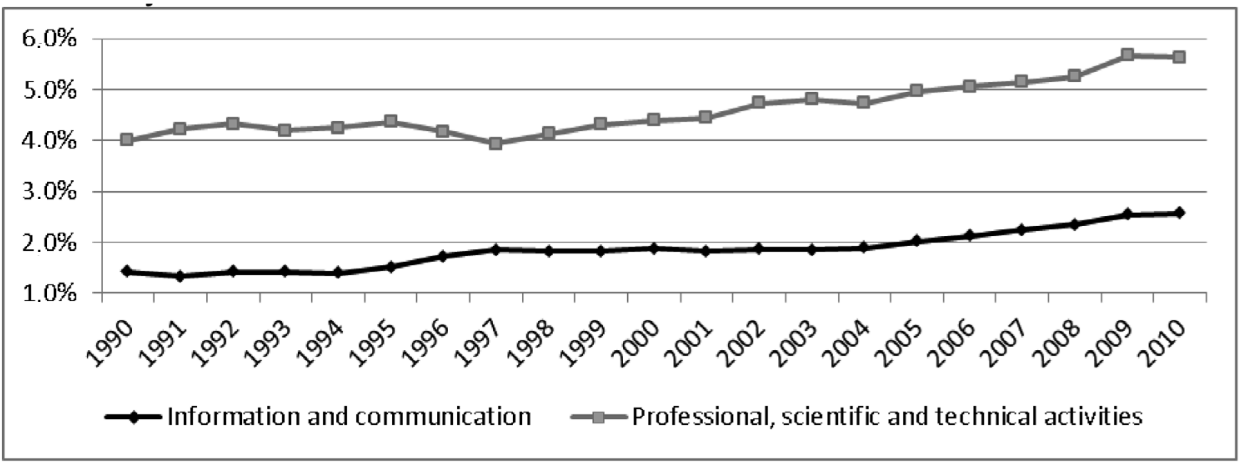

Source: Czech Statistical Office; own calculations

Fig. 5:

The average monthly salary in the national economy - by the areas (CZ-NACE). In thousands CZK/employee, common prices

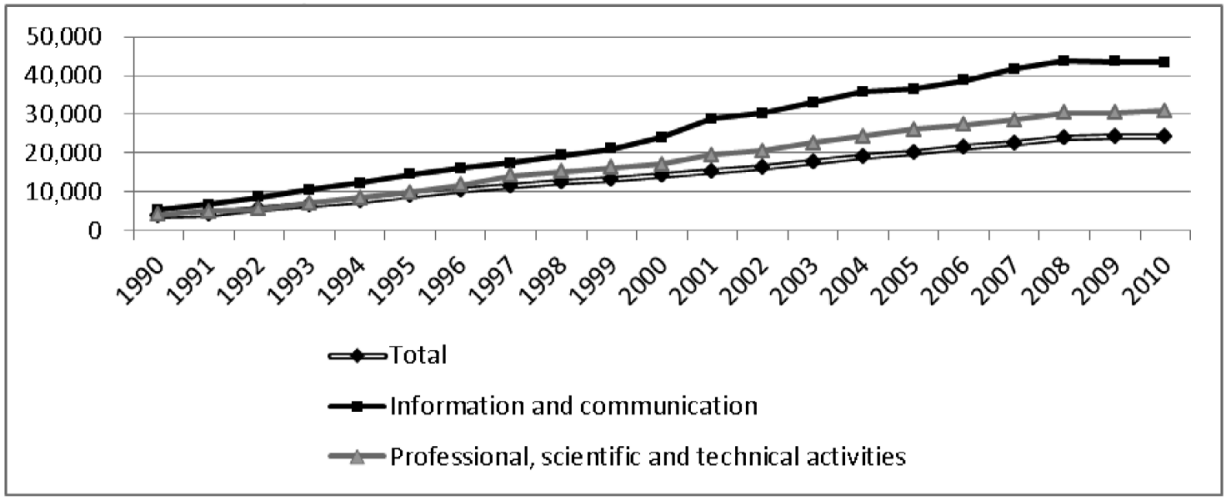

Source: Czech Statistical Office; own calculations

The complete overview of the creative industry development to the total economy development is presented in the Table 2. At selected indicators the change within the period is indicated $(\Delta 5$ years $=2005 / 2010 ; \Delta 10=$ $=2000 / 2010 ; \Delta 15=1995 / 2010)$. The basic indicator related to the production of creative industry confirms the assumption that these specific areas would reach the higher outcomes than the total economy. This fact was confirmed in all observed periods.

The analogous is the export of the creative industries products. The export of the PSTa area did not reach such an increase as a total export in the observed 15 year period. However, it has been acquiring the intensity recently and the average values of export are exceeded. 


\begin{tabular}{l|c|c|c|c} 
& & $\begin{array}{c}\text { Information } \\
\text { and } \\
\text { communication }\end{array}$ & $\begin{array}{c}\text { Professional, } \\
\text { scientific and } \\
\text { technical activities }\end{array}$ & Total \\
\hline Production - by sector (NACE) & $\Delta 5$ years & 30.5 & 30.9 & 22.2 \\
mil. CZK, current prices & $\Delta 10$ years & 87.8 & 96.5 & 69.4 \\
\hline Exports of goods and services & $\Delta 15$ years & 355.6 & 213.7 & 161.9 \\
(fob) - according to type (CZ-CPA) & $\Delta 10$ years & 57.2 & 88.2 & 28.0 \\
mil.CZK, current prices & $\Delta 15$ years & 235.1 & 104.6 & 86.3 \\
\hline Imports of goods and services & $\Delta 5$ years & 433.3 & 98.4 & 249.5 \\
(cif) - according to type (CZ-CPA) & $\Delta 10$ years & 45.3 & 32.3 & 27.4 \\
mil. CZK, current prices & $\Delta 15$ years & 296.7 & 13.8 & 71.6 \\
\hline Workers in the national & $\Delta 5$ years & 30.0 & 84.0 & 210.0 \\
economy - by sector (NACE) & $\Delta 10$ years & 41.5 & 15.8 & 2.0 \\
number of employees & $\Delta 15$ years & 67.2 & $\mathbf{3 2 . 3}$ & 3.4 \\
\hline Wages and salaries - by & $\Delta 5$ years & 48.1 & 36.1 & -1.5 \\
\hline industry (NACE) & $\Delta 10$ years & 142.9 & 109.6 & 21.7 \\
mil. CZK, current prices & $\Delta 15$ years & 375.0 & 221.9 & 13.1 \\
\hline Average monthly salaries in & $\Delta 5$ years & 19.3 & 18.0 & 22.0 \\
the national economy - by & $\Delta 10$ years & $\mathbf{8 1 . 2}$ & $\mathbf{8 0 . 6}$ & 72.7 \\
sector (NACE) & & & & \\
thousand CZE per empl., current & $\Delta 15$ years & 201.1 & 214.2 & 175.4 \\
prices & & & & \\
\hline & & & & \\
\hline
\end{tabular}

Source: Czech Statistical Office; own calculations

The creative industries have been creating a huge amount of job vacancies. This trend is confirmed also in the Czech Republic. The ratio of employees within creative industry has been increasing during the time. The ratio has increased by $30 \%$ in laS and by $15.8 \% \mathrm{n}$ PSTa in the last 5 years. The similar increase was detected also within the salaries paid in the creative industry.

Regarding the average salary there is a significant increase within the long period. In comparison to the national economy the salaries within the creative industries have raised by $25.7 \%$ in the laC and $38.8 \%$ in PSTa $(\Delta 15)$. The opposite trend has been detected within the last 5 years when the average increase in creative industry salaries was below the growth in the whole economy. This fact can be explained by the global economic crisis. Many posts within the creative industry are very flexible therefore the decline of the demand affects the salary level more quickly. However, speaking in the absolute numbers the level of the salaries within the creative industries is definitely higher than the level of the average salary in the national economy. The average salary was $24,377,-$ CZK, and it was 43,450 within laC and 30,849 within PSTa in 2010.

The paper considers not just the national level, but it analyses also the representation of the creative industries within the individual regions of the Czech Republic. The Creative Industries Index was created for this analysis (CII). Its construction is based on the ratio of creative industries on the total production and the ratio of people employed in creative industries to the total manpower.

The CII was determined for each region for the years 2009 and 2010. The highest representation according to CII occurs in capital city of Prague. The second position belongs to the region of South Moravia. The both these regions are tied to the two biggest cities of the Czech Republic. This confirms the assumption that the creative industry is mainly concentrated in the big agglomerations. This is 


\section{Ekonomie}

underlined by the region on the third position which is geographically tightly connected with the capital city of Prague. The other side of the figure belongs to the region of Karlovy Vary which is famous for its recreational potential.

\section{Fig. 6: Creative Industries Index for the Czech Republic regions}

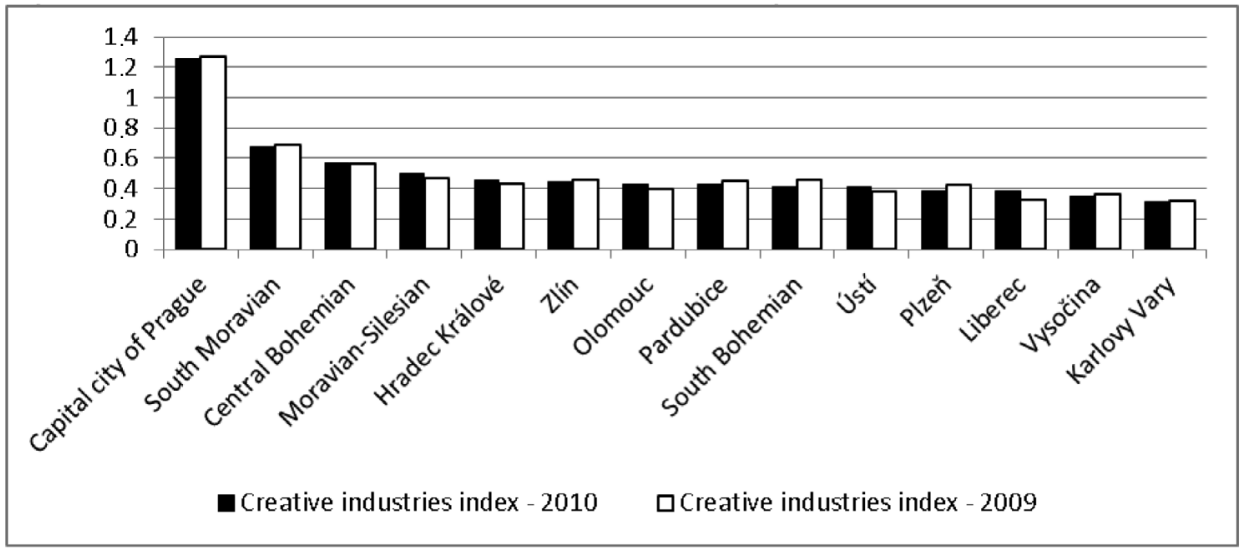

Source: Czech Statistical Office; own calculations

The Cll serves not just for mapping of the creative industries in the regions but it also contributes to an analyzing of the relation between creative industries and economic level in the regions. The hypothesis was formulated in the introduction; this presumes the positive correlation between the creative industry presence and some macroeconomic indicators. This was confirmed with the use of correlation analysis. The outcomes are captured in the Table 3. Regions with higher level of the $\mathrm{Cll}$ in most cases reach a higher GDP, more job vacancies and higher average salaries.

The Table 3 sets the values of a correlation coefficient. The closer are the values to 1 the higher is the mutual connection of individual indicators. The $\mathrm{Cll}$ itself reached the tight connection to in the relation to open job vacancies by the correlation coefficient of 0.51 in 2010 . The relation was even more significant in previous year. The correlation analysis of $\mathrm{Cll}$ and its relation to GDP indicators was fluctuating around 0.95 of correlation coefficient. Identically, the fact is confirmed within individual the sections of the creative industry by the relation to production and to employees in the creative regions.

According to the table 3 creative industries contribute to the development of the economic level of the whole region. The high positive correlation between $\mathrm{Cll}$ and GDP indicators confirms that. To analyze this relation closely the Figure 7 was created. This figure captures all researched regions. The GDP per capita indicator is captured on the $x$ axis, the Cll in 2008 is captured on the axis y. With all regions captured in the figure the linear trend and coefficient of dominance were determined. They confirm the tightness.

It is obvious that one region is beyond from the researched range. The region of capital city of Prague is found in the upper part of the figure. This region detects the significant presence of creative industries and together with higher economic level. Other regions stagnate at first sight.

For the record the range was analyzed repeatedly without the capital city of Prague. This means that the region which significantly differs from the rest was removed. The following correlation analysis examined the relation between CII and GDP per capita. The correlation coefficient was 0.77 what is still positive correlation. 
The relation between creative industry and macroeconomic indicators showed by the correlation coefficient

\begin{tabular}{lccccc} 
& Year & Vacancies & $\begin{array}{c}\text { GDP per } \\
\text { capita } \\
\text { (CZK) }\end{array}$ & $\begin{array}{c}\text { GDP per } \\
\text { person empl. } \\
\text { (CZK) }\end{array}$ & $\begin{array}{c}\text { Net cash } \\
\text { income } \\
\text { (CZK) }\end{array}$ \\
\hline Businesses by CZ-NACE principal activity & & & & & \\
\hline Information and communication & 2010 & 0.508 & 0.936 & 0.941 & 0.874 \\
& 2009 & 0.794 & 0.954 & 0.964 & 0.902 \\
\hline Professional, scientific and technical activities & 2010 & 0.376 & 0.860 & 0.872 & 0.740 \\
& 2009 & 0.679 & 0.862 & 0.876 & 0.749 \\
\hline The employed in the national economy by CZ-NACE & & & & \\
\hline Information and communication & 2010 & 0.587 & 0.969 & 0.961 & 0.908 \\
& 2009 & 0.841 & 0.971 & 0.975 & 0.909 \\
\hline Professional, scientific and technical activities & 2010 & 0.506 & 0.912 & 0.879 & 0.849 \\
& 2009 & 0.876 & 0.958 & 0.938 & 0.913 \\
\hline Creative industries & & & & & \\
\hline Creative industries index & 2010 & 0.540 & 0.957 & 0.947 & 0.888 \\
& 2009 & 0.840 & 0.973 & 0.973 & 0.910 \\
\hline
\end{tabular}

Fig. 7: The relation between Creative industries index and GDP per capita (2010)

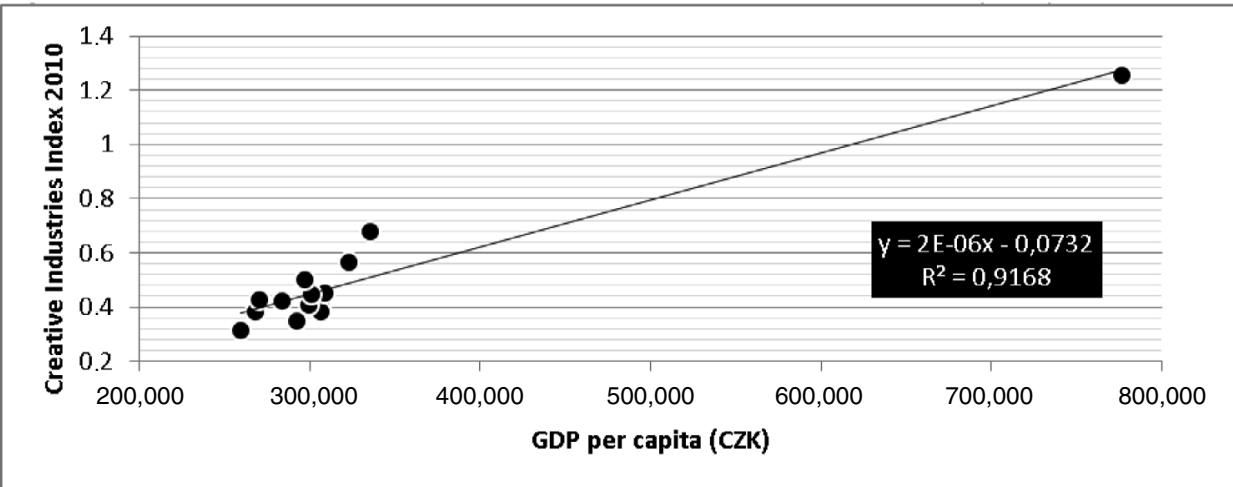

Source: Czech Statistical Office; own calculations

We can conclude on the basis of the analysis that the presence of the creative industries within the region has an important impact on the region. These impacts are reflected by creation of new job vacancies or the increase of the production expressed by GDP. If the regions want to maintain the competitiveness, they should aim the support at the creative industries. This would indirectly support the future development.

\section{Conclusions}

The creative industries have become the significant part of the economy of the developed countries. The proportion of in the total production is still increasing and creative industries employ more and more labour. The goal of this paper was to analyse the situation of creative industries in the Czech Republic. For this purpose the work defined the creative 
industries by the statistic classification of the economic activities (NACE). This classification is used by Czech Statistical Office and EUROSTAT. Despite the significant simplification the structure has been effective and it confirmed the selected hypothesis.

The first hypothesis presumed the growth in importance of the creative industries in the Czech Republic. The work analyzed the period from the time when the Czech Republic entered the market environment (1990) to year 2010. In comparison to the national economy the significant increase in production and export was confirmed within the creative industries. The proportion of the people employed within the creative industry was increased too in compare to total employment in the economy. These people reaches higher salaries and pays more money directly or indirectly back to state budget.

The direct relation between the presence of the creative industries and economy of the region was confirmed while testing the second hypothesis of this work. The Creative Industries Index (CII) was created to verify this hypothesis. The index enabled to measure the presence of the creative industries within the regions of Czech Republic. The following correlation analysis proved extremely strong positive relation between the presence of creative industries and selected macroeconomic indicators. These indicators are GDP, job vacancies and average income.

On the basis on the outcomes, the contribution of the creative industries to national and regional development is more than significant. The aimed support of these industries should positively influence the development and competitiveness of the region. This statement should be confirmed by analysis within the other developed countries.

Authors are thankful to the Internal Grant Agency of FaME UTB No. IGA/FaME/2013/033 for financial support to carry out this research.

\section{References}

[1] BEDNÁŘ, P., GREBEnÍČEK, P. Mapping Creative Industries in the Zlin Region. Journal of Competitiveness. 2012, Vol. 4, Iss. 1, pp. 20-35. ISSN 1804-1728.

[2] CIKÁNEK, M. Kreativní průmysly př́ležitost pro novou ekonomiku. Praha: Institut umění - Divadelní ústav v Praze, 2009. ISBN 978-80-7008-231-7. [3] FLEW, T. Beyond ad hocery: Defining the creative industries. In Cultural Sites, Cultural Theory, Cultural Policy [online]. Wellington (New Zealand): Te Papa. 2002, Iss. 1 [cit. 2013-03-15], pp. 23-26. Available from: <http://eprints.qut. edu.au/256/1/Flew_beyond.pdf $>$.

[4] FLORIDA, R. The Rise Of The Creative Class: And How It's Transforming Work, Leisure, Community And Everyday Life. New York: Basic Books, 2002. ISBN 0465024769.

[5] HARTLEY, J. Creative Industries. Wiley: WileyBlackwell, 2004. ISBN 978-1405101486.

[6] HESMONDHALGH, D. Creative Industrie. 2nd ed. London: Sage Publications, 2007. ISBN 1412908086.

[7] HOWKINS, J. The Creative Economy: How People Make Money From Ideas. 2nd ed. London: Penguin Global, 2004. ISBN 978-0140287943.

[8] JACOBS, J. The Death and Life of Great American Cities. New York: Random House, 1961. ISBN 0-679-60047-7.

[9] JACOBS, J. The Economy of Cities. New York: Random House, 1969. ISBN 039470584X.

[10] JIRÁSKOVÁ, E., ŽIŽKA, M. The Significance of Business Localization Factors in the Czech Republic. Creative and Knowledge Society. 2012, Vol. 1, Iss. 2, pp. 16-36. ISSN 1338-4465.

[11] JIRČíKOVÁ, E. Kreativní průmysl a jeho výkonnost. In Sborník príspěvků z mezinárodní vědecké konference Finance a výkonnost firem ve vědě, výuce a praxi. Zlín: Univerzita Tomáše Bati ve Zlíně, 2009. ISBN 978-80-7318-798-9.

[12] KLOUDOVÁ, J. Kreativní ekonomika a její měření. Ekonomický časopis / Journal of Economics. 2009, Vol. 57, Iss. 3, pp. 247-262. ISSN 0013-3035. [13] KLOUDOVÁ, J., CHWASZCZ, O. Transformation of 3t Model towards the Comparison of Creative Centres within the European Union. E+M Ekonomie a Management. 2012, Vol. 15, Iss. 4, pp. 56-70. ISSN 1212-3609.

[14] KLOUDOVÁ, J., CHWASZCZ, O. New Way of Analysis of Creative Centers within Europe. Economics and Management. 2011, Vol. 16, pp. 197-206. ISSN 1822-6515.

[15] KRAFTOVÁ, I., KRAFT, J. High tech firmy a tvorba bohatství v zemích EMEA. E+M Ekonomie a Management. 2010, Vol. 13, Iss. 4, pp. 4-20. ISSN 1212-3609.

[16] LANDRY, C. The Creative City: A Toolkit for Urban Innovators. Near Stroud: Comedia/ /Earthscan, 2000. ISBN 978-1853836138. 
[17] RUMPEL, P., SLACH, O., KOUTSKÝ, J. Creative Industries in Spatial Perspective in the Old Industrial Moravian-Silesian Region. E+M Ekonomie a Management. 2010, Vol. 13, Iss. 4, pp. 30-46. ISSN 1212-3609.

[18] UNCTAD. Creative Economy report 2008 [online]. The United Nations, 2008 [cit. 2013-03-15]. 357 p. (PDF). ISBN 978-0-9816619-0-2. Available from: http://unctad.org/en/docs/ditc20082cer_en.pdf. doc. Ing. Jitka Kloudová, Ph.D.

Tomas Bata University in Zlín

Faculty of Management and Economics

Department of Economics

Pan European University kloudova@fame.utb.cz

Ing. Ondřej Chwaszcz

Tomas Bata University in Zlín

Faculty of Management and Economics

Department of Economics chwaszcz@seznam.cz 


\section{Abstract}

\section{THE ANALYSIS OF THE CREATIVE INDUSTRY LINKED IN CONNECTION WITH THE ECONOMIC DEVELOPMENT Jitka Kloudová, Ondřej Chwaszcz}

The paper analyses the development of the creative industries in the Czech Republic during the years 1990-2010. The specification of creative industries is undertaken on the basis of the concept of creative economy and is based on the basic classification of the economic activities (NACE). This classification is used by most of the European statistic offices.

The study is analyses the development of creative industries in relation to the basic economic indicators (production, employment, net income and export). Each analyzed parameter proves a faster development than the overall average indicators. Production of the creative industries, which increased in the period $2005 / 2010$ by $30 \%$ compared to $22 \%$ of the national average, is used as an example. Such results demonstrate the positive impact of creative industries to the economy. A similar effect has been demonstrated for other analyzed indicators. Employment in the creative industries has risen also very rapidly over the time. Moreover, the incomes in this industry are higher compared to the average. This leads to the stronger demand and in addition, it ensures higher payments to government budgets.

Furthermore, the study analyses the impact of creative industries in every region of the Czech Republic. For this purpose, the Creative Industries Index (CII) was created. Its design is based on the share of creative industries in total production and at the same time it is based on the proportion of employees working in the creative industry in comparison to the total labor force. As a next step, the study uses correlation analysis to establish the link between Cll and selected macroeconomic indicators (GDP, vacancies, and incomes). In each case, the positive and high level degree of correlation was found. As a result, this study confirms the significant contribution of creative industries that help to maintain and develop a regional competitiveness.

Key Words: Creative industries, creative industries index, creative economics, regional development.

JEL Classification: E23, O11, R11.

DOI: 10.15240/tul/001/2014-1-003 